\title{
Relation between protein efficiency and net protein utilization
}

\author{
By A. E. BENDER \\ Bovril Ltd, I48 Old Street, London, E.C. I \\ (Received I5 December I955)
}

The simplest and most convenient method of measuring the nutritive value of proteins is by an assessment of the protein efficiency ratio (P.E.R.) (gain in weight in $\mathrm{g} / \mathrm{g}$ protein eaten). This measurement has been frequently criticized and, in fact, Mitchell (1924) stated that simplicity was its only recommendation. There are two main drawbacks to the method. Firstly, P.E.R., as measured on any particular protein, increases with the quantity of protein consumed (Mitchell, I924, r944; Barnes, Maack, Knights \& Burr, I945; Stewart, Hensley \& Peters, I943). A certain amount of protein is required for maintenance of body-weight, and only the increment above this amount is available for growth. Consequently, when larger quantities are consumed more is available for growth and a higher P.E.R. results. Secondly, the method is based on the assumption that the increase in body-weight on the protein-containing diet is proportional to the protein retained. It has been repeatedly shown that the composition of the weight increase varies with the type of diet during the 6-8 weeks of the usual experiments (Mitchell \& Carman, r926; Hamilton, 1939; Kik, 1938).

The more complex method of determining the nutritive value of protein, namely, measurement of biological value (B.V.) or net protein utilization (N.P.U.), which represents the percentage of the absorbed or fed protein retained in the body, is not subject to these drawbacks. The B.v. is constant irrespective of the quantity of protein fed as long as that quantity does not exceed the animal's capacity to synthesize body protein.

A number of proteins and amino-acid mixtures have been examined both for P.E.R. and N.P.U. and the results compared. A preliminary report of this work has been published by Bender (1955).

\section{EXPERIMENTAL}

Animals. Albino rats of both sexes, 28-30 days old, were used, usually about $35-45 \mathrm{~g}$ in weight. A few rats of this age reached a weight of $60-70 \mathrm{~g}$.

Grouping. In each series of experiments four litters of eight rats were divided into eight groups of four so that every group contained one rat from each litter and the total weight of each group was the same. In this way seven proteins were tested in each series of experiments, the eighth group being fed on the non-protein diet. Each group was housed in one cage and the food consumption was measured for the whole group.

Diet. The basal diet, patterned on that of Henry, Kon \& Watson (1937), was: potato starch 10 , glucose $I_{5}$, rice starch 55 , margarine fat $1_{5}$ and salt mixture $5 \%$. All the known vitamins were added in the quantities used by Folley, Henry \& Kon (1947), together with vitamin $B_{12}$. Proteins and amino-acid mixtures to be tested 
replaced the rice starch in such quantity that the experimental diet contained $\mathrm{I} \cdot 4-\mathrm{I} \cdot 6 \%$ nitrogen.

Amino acid mixtures. The following mixtures were used:

(A) A mixture of the essential amino-acids in the same proportions as in egg protein according to the analysis quoted by Block \& Mitchell (1946-7), with glycine as the sole source of non-essential amino-acids;

(B) The mixture of essential amino-acids used by Rose, Smith, Womack \& Shane (I949) (mixture XXVI), with the non-essential $\mathrm{N}$ derived from glycine, arginine, alanine, glutamic acid and ammonium citrate;

(C) mixture $B$ with the proportion of essential amino-acids decreased by $15 \%$;

(D) a mixture of essential amino-acids in the same proportion as in egg protein according to the analysis of the Rutgers University: Bureau of Biological Research (undated), with the non-essential $\mathrm{N}$ as in mixture $\mathrm{B}$;

(E) mixture $\mathrm{D}$ with the proportion of essential amino-acids decreased by $15 \%$.

Net protein utilization and protein efficiency ratio. N.P.U. was determined by the method of Bender \& Miller (1953) and Miller \& Bender (1955) with the modification that later experiments were completed in 7 days instead of 10 . The shorter period gave the same results as the longer one. P.E.R.'s were determined on the same rats.

In this method there is no acclimatization period, the rats going straight from stock diet to the experimental diet at the beginning of the experiment.

The animals were weighed to the nearest $g$ on alternate days and immediately before killing. After killing they were weighed to the nearest $0 . I \mathrm{~g}$. The live weights were used to calculate P.E.R.'s and the dead weights to calculate the moisture content and hence the estimated $\mathrm{N}$ content. In calculating the food intake/roo $\mathrm{g}$ body-weight of each group of rats the initial body-weight was used.

\section{RESULTS AND DISCUSSION \\ Variation of P.E.R. with food intake}

Roller-dried skim milk was assayed six times with the results shown in Table I. The N.P.U.'s were constant within the accuracy of the method and the P.E.R.'s varied considerably. Food was always given ad lib., but consumption varied from one experiment to another, being I22, I45, I 54, I45, I I 2, I05 g food/100 $\mathrm{g}$ body-weight respectively. The variation in P.E.R. was due, in part at least, to the variation in food intake as the correlation between P.E.R. and food intake/I00 $\mathrm{g}$ body-weight was $0.9 \mathrm{I} 5$ $(P=0.01)$ (Fig. I).

Similarly, bread fortified with lysine $(2 \%$ of the total protein) was assayed four times; N.P.U.'s were constant and P.E.R.'s varied very widely (Table I). Here again P.E.R.'s correlated with food consumption, 86, 96, Ir 3 , and $\mathrm{I} 39 \mathrm{~g}$ food/roo g bodyweight respectively $\left(r=0.95^{8}\right)$ (Fig. I).

\section{Effect of nutritive value of protein on food consumption}

In view of the overriding importance of the quantity of food consumed, the dependence of food consumption upon the nutritive value of the protein of the diet was examined. With thirty-two proteins, ranging in N.P.U. from 5 to 93 , food intakes 
Table 1. Variations in replicate determinations on groups of four rats of protein efficiency ratio and net protein utilization

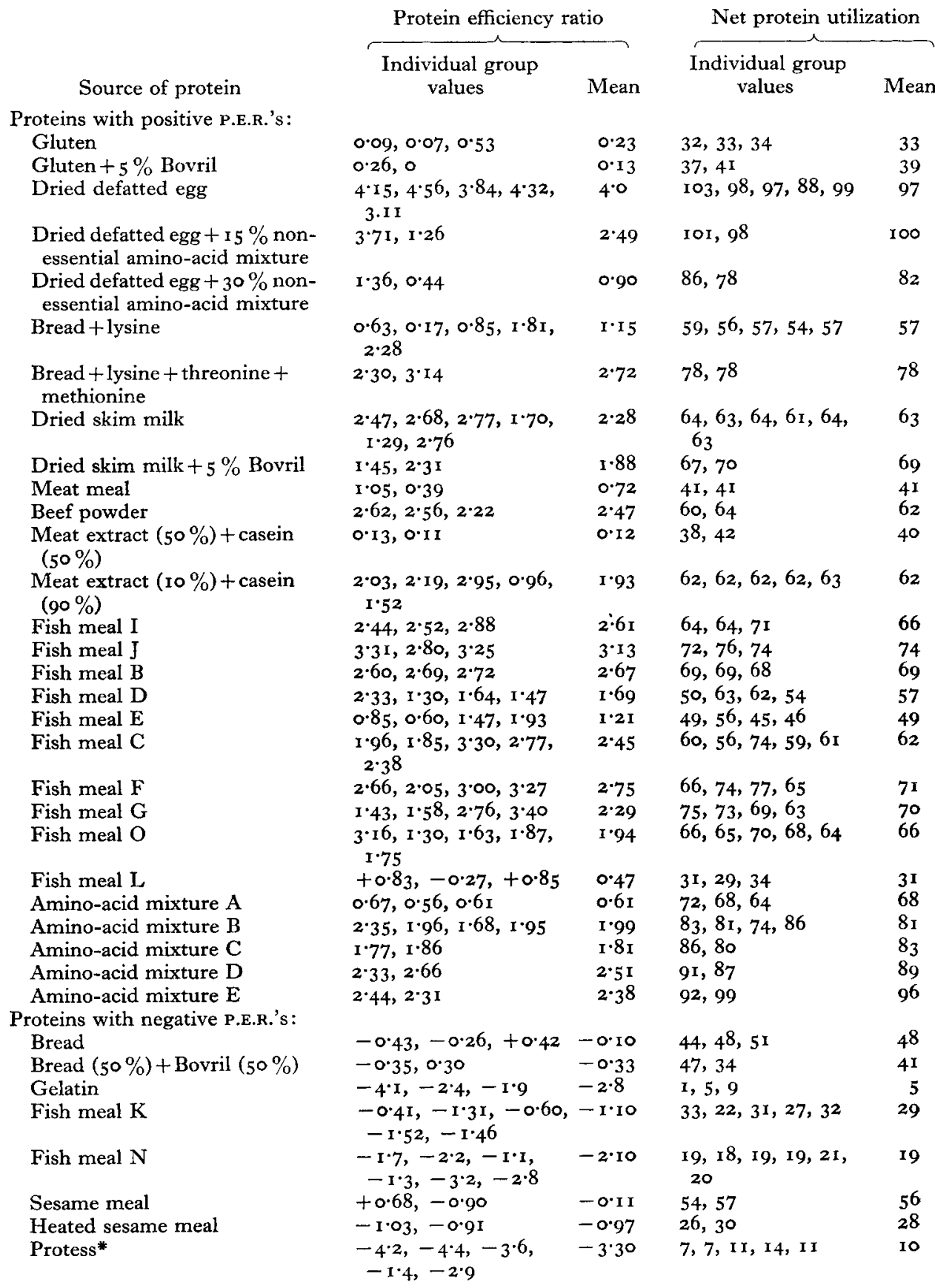

* A grass-protein concentrate prepared in a commercial plant. 
(g/100 g body-weight) correlated highly significantly with N.P.U. (Fig. 2); $r=0.789$, $y^{2}=67 x-389$ I $(y=$ N.P.U., $x=$ food intake); $P<0.01$.

In a similar fashion food intakes correlated highly significantly with P.E.R. (Fig. 3); $r=0.9 \mathrm{I} 8, y^{2}+20 y=\mathrm{I} \cdot 55^{x}-\mathrm{I} 35^{\circ} 4$.

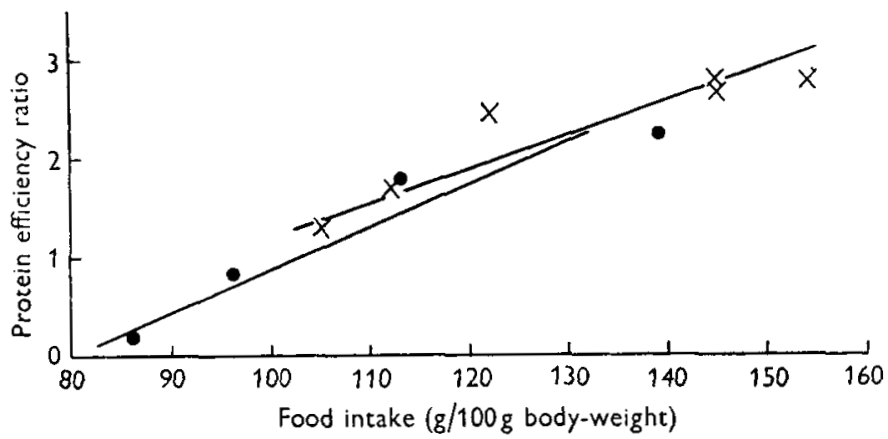

Fig. I. Relation between protein efficiency ratio and food intake in $\mathrm{g} / \mathrm{r} 00 \mathrm{~g}$ body-weight for roller-dried skim milk, and bread fortified with lysine. $x$, dried skim milk; 0 , bread +lysine.

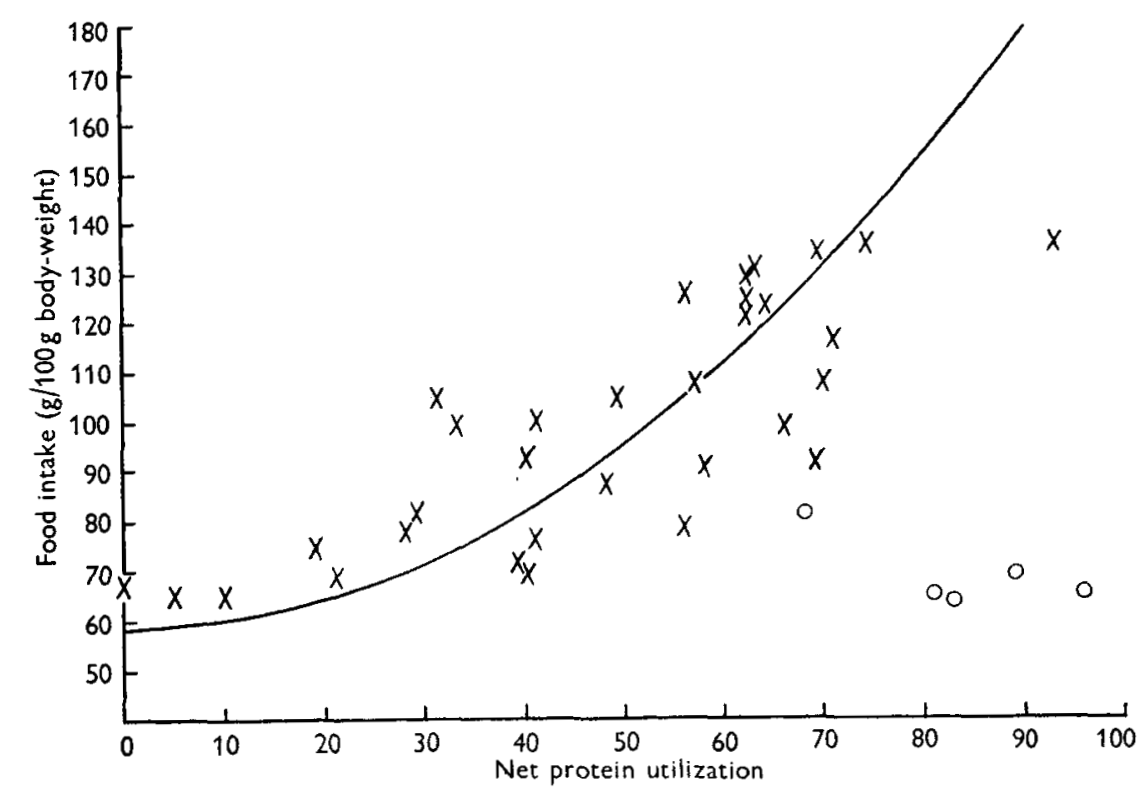

Fig. 2. Relation between total food intake in $\mathrm{g} / \mathrm{x} 00 \mathrm{~g}$ body-weight and net protein utilization of the protein of the diet. Regression for thirty-two proteins: $y^{2}=67 x-389 \mathrm{r}(y=$ N.P.U., $x=$ food intake); $r=0.789$. $O$, values for diets composed of synthetic amino-acids, not included in regression.

The food consumption on the non-protein diet was remarkably constant, being, in eighteen experiments (each of 10 days' duration), $68 \pm \mathrm{I} \cdot 5$ (S.E.) $\mathrm{g}$ food/100 g bodyweight. 'The food intakes on proteins of low nutritive value, e.g. gelatin (N.P.U. = 5) and grass protein (N.P.U. $=10$ ), were the same as on the non-protein diet. The difference between food consumption on the poorest and on the best proteins was about $100 \%$. 
Relation between P.E.R. and N.P.U.

The P.E.R.'s of twenty-one proteins were compared with their N.P.U.'s determined in the same experiment. The values quoted were the means of several estimations, even where it meant, as with bread fortified with lysine, that a mean had to be taken of values ranging from $0 \cdot 2$ to $2 \cdot 3$. The correlation between N.P.U. and P.E.R. was highly significant (Fig. 4); $r=0.803$, the regression equation being $y=40 \cdot 0+12 \cdot 6 x$. This equation agrees very well with that found by Block \& Mitchell (1946-7), who calculated the N.P.U. from the results of balance experiments; $y=37^{\circ} 2+14.05 x$, $r=0.838$.

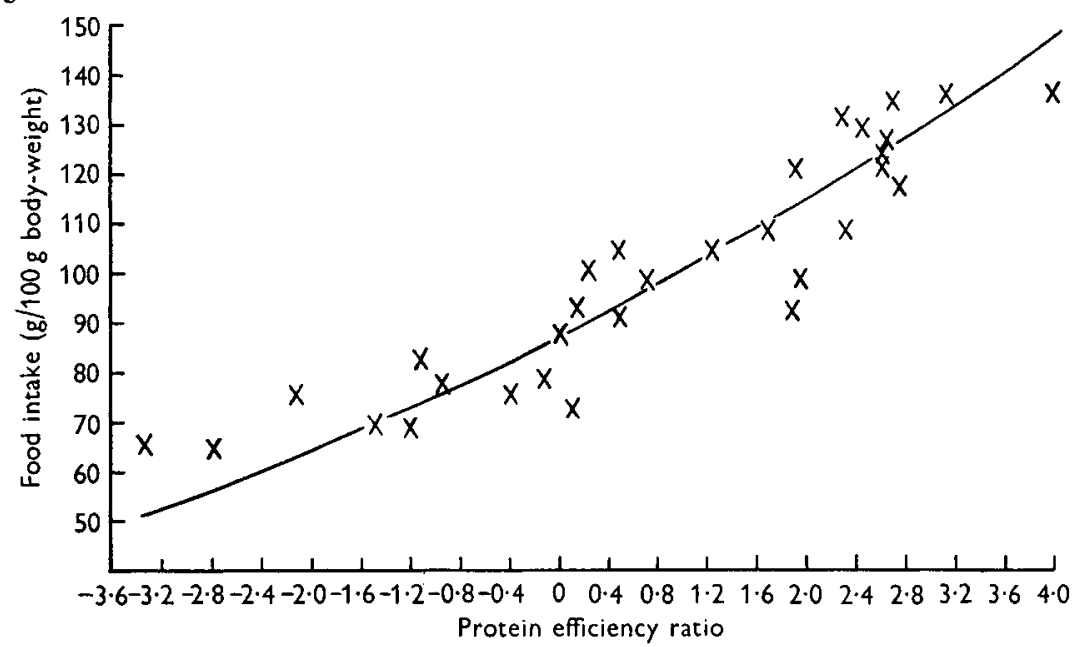

Fig. 3. Relation between total food intake in $\mathrm{g} / \mathrm{I} 00 \mathrm{~g}$ body-weight and protein efficiency ratio. Regression of thirty-one proteins: $y^{2}+20 y={ }_{1} \cdot 55^{x}-135^{\circ} 4(y=$ P.E.R., $x=$ food intake); $r=0.918$.

In view of the variation of P.E.R. with food intake it might be argued that the highest P.E.R. (obtained in experiments in which food consumption was highest) is the nearest approach to the correct answer. The regression was determined of the maximum observed P.E.R. for each protein with the mean N.P.U. It is also shown in Fig. 4, and does not differ appreciably from the regression line calculated from the mean P.E.R.'s: $y=35 \cdot 4+\mathrm{II} \cdot 9 x, r=0.780$. Table I shows the extent of the range of P.E.R. estimations, and the values used to calculate the two regression lines.

\section{Negative P.E.R.}

The relation between N.P.U. and P.E.R. (Fig. 4) indicates that when N.P.U. is less than 40 , rats are unable to grow on the experimental diet and, therefore, P.E.R. cannot be measured. It should be possible, however, to determine negative P.E.R.'s, i.e. the loss of weight per $g$ protein eaten. This loss would be small for proteins of mediocre quality but large for poor proteins. The regression between P.E.R. and N.P.U. for fourteen proteins with N.P.U. less than 60 (i.e. where P.E.R. is a very small positive quantity or is negative) was $y=40 \cdot 7+8 \cdot I x(r=0 \cdot 673)$ in contrast to that of higher N.P.U. (Fig. 4). The change in slope was probably due to the reduced consumption of prote ins of low quality, of which the P.E.R.'s were consequently underestimated. 


\section{Synthetic amino-acid diet}

It has been shown (Fig. 2) that the food consumption is related to the N.P.U. of the protein of the diet, but this relation does not hold for diets containing synthetic amino-acids as the sole source of N. For example, mixture A had N.P.U. 68 which, according to Fig. 2, corresponds to a food consumption of $130 \mathrm{~g} / \mathrm{1} 00 \mathrm{~g}$ body-weight. In five experiments the food intakes were $86,85,94,72$ and $73 \mathrm{~g} / \mathrm{roo} \mathrm{g}$ body-weight. Amino-acid mixtures B, C, D and E were similarly consumed in smaller quantities than would be expected from their N.P.U.'s. A factor of palatability would appear to be more potent than that of N.P.U. in influencing food intake.

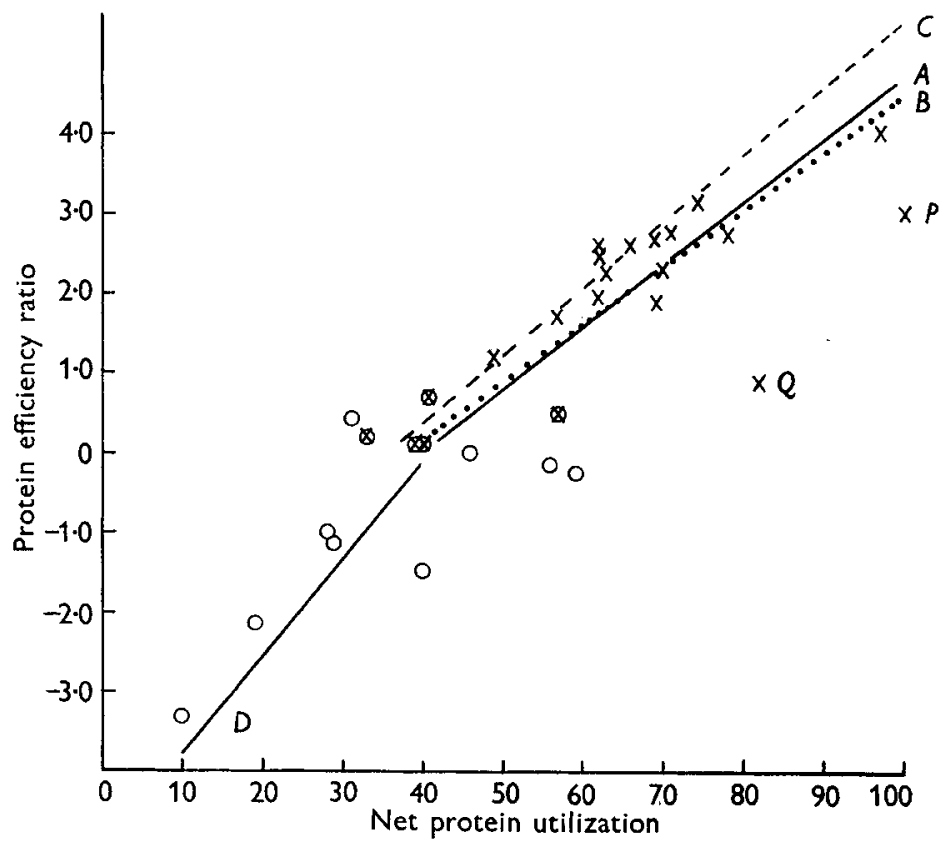

Fig. 4. Relation between protein efficiency ratio and net protein utilization. (A) Relation between N.P.U. and P.E.R.'s with positive values (crosses): $y=40 \cdot 0+\mathrm{I} 2 \cdot 6 x(y=$ N.P.U., $x=$ P.E.R. $) ; r=0.805$; $n=2$ I. $P$, egg protein with $15 \%$ of a mixture of non-essential amino-acids; $Q$, egg protein with $30 \%$ of a mixture of non-essential amino-acids. (B) Relation between N.P.U. and P.E.R. shown by Block \& Mitchell (1946-7): $y=37 \cdot 2+14.05 x ; r=0.838 ; n=38$. (C) Relation between N.P.U. and maximum observed P.E.R.'s: $y=35.4+11 \cdot 9 x ; r=0.780 ; n=2 \mathrm{I}$. (D) Relation between N.P.U. and P.E.R.'s with negative or very low positive values (open circles): $y=40 \cdot 7+8 \cdot 1 x ; r=0.673$; $n=\mathrm{I} 4$.

This depressed food intake on a diet of synthetic amino-acids yields a completely incorrect P.E.R. The N.P.U.'s were determined on five different mixtures of amino-acids, A, B, C, D and E ('Table 2). From Fig. 4 the P.E.R.'s corresponding to these N.P.U.'s can be derived. The measured P.E.R.'s (Table 2) were much lower than these expected values. 
Table 2. Calculated and observed protein efficiency ratios and food consumption of rats receiving mixtures of synthetic amino-acids

N.P.U.

P.E.R. derived from Fig. 4

Mixture E Mixture D

Mixture C
83
$3 \cdot 4$
$\mathrm{I} \cdot 8$
$\mathrm{I} 6 \mathrm{I}$

Mixture B

Mixture A

Expected food intake derived from Fig. 2 195 ( $\mathrm{g} /$ roo $\mathrm{g}$ body-weight)

Actual food intake $(\mathrm{g} / \mathrm{1}$ oo $\mathrm{g}$ body-weight $) \quad 65$

89
$3 \cdot 8$
$2 \cdot 5$
176
69

63

$\begin{array}{cc}8 \mathrm{I} & 68 \\ 3 \cdot 2 & 2 \cdot 2 \\ 2 \cdot 0 & 0 \cdot 6 \\ 156 & 127 \\ & \end{array}$

\section{Errors in P.E.R. through inadequate intake}

The type of error that can arise in the use of P.E.R. is exemplified by a study of the work of White, Alvistur, Días, Viñas, White \& Collazos (1955). These authors showed that the P.E.R. of quinua (Chenopodium quinoa Willd.) protein was apparently similar to that of milk. From their data it is clear that the consumption of the milk diet was low, and hence, according to our findings, the P.E.R. artificially depressed. Their results bear out this contention as they found a P.E.R. for milk of $\mathrm{I} \cdot 46$ and $\mathrm{I} \cdot 6 \mathrm{I}$ in two experiments, whereas it is $2 \cdot 8$ according to Block \& Mitchell (1946-7), or ranged from $\mathrm{I} \cdot 3$ (on low food intake) to $2 \cdot 8$ (on high intake) in the present work (Table I). Thus the conclusion reached by White et al. that the protein quality of quinua is at least equal to that of milk is not necessarily correct.

\section{Length of experimental period}

Fixsen (1934-5) stated that a long experimental period is essential for the measurement of P.E.R., short experiments giving higher values than the long ones, and 60 days being the minimum duration required for accuracy. The periods usually used by various authors vary between 4 and 7 weeks (Mitchell, 1944; Kik, 1938). In our experiments 10-day and 7 -day experimental periods were used, and as the results obtained correlate as well with N.P.U. as do those of Block \& Mitchell (1946-7) this period appears to be adequate.

It is possible that the shorter periods might be preferable as Mitchell (1924) pointed out that as 'the composition of the gains put on by growing animals progressively changes with age...the best way of assuring the desired equality in the composition of gains... is to use animals of the same age, weight, and previous treatment and to conduct the experiments for as short periods of time as may be required for an accurate measure of the actual gain in organized tissue'. If the experiment is prolonged over several months with proteins differing greatly in nutritive value, the disparity of gains probably indicates gains of distinctly different composition. However, in some of the experiments reported here the results, owing to low food intake, were abnormally low, and a longer experimental period might allow a more consistent food consumption.

\section{Value of P.E.R. determinations}

With all the drawbacks it is surprising that the average P.E.R.'s correlate so well with N.P.U. The agreement with the findings of Block \& Mitchell (1946-7) is remarkably close in view of the fact that these authors correlated data on thirty-nine proteins from 
a large number of different laboratories, mostly with P.E.R. determined in one laboratory and N.P.U. in another, whereas the present report correlates data for N.P.U. and P.E.R. obtained not only in one laboratory but in the same experiment.

The results reported here only partly support the general criticism of P.E.R. as a means of measuring protein quality. When the mean of several estimations, even with an unusually brief experimental period, is taken, P.E.R. gives a measure of nutritive value which is as useful as N.P.U. and simpler to determine (although very little simpler than the dry-weight modification of Miller \& Bender (1955)).

However, the present results show that if P.E.R. is measured in a single ro-day experiment (and if it is simplicity that recommends the method such will obtain) the result might be completely invalidated because of inadequate food intake, and there would be no indication that the result was not acceptable.

The results suggest that application of the abbreviated P.E.R. method to synthetic amino-acid mixtures yields incorrect values.

\section{SUMMARY}

I. The net protein utilization and the protein efficiency ratio were determined in the same experiment on thirty-two proteins and five amino-acid mixtures. Groups of four rats were used in each test and the results for each group combined. The duration of each experiment was 7 or Io days.

2. The P.E.R. correlated closely with food intake, falling when the food consumption was reduced. The N.P.U. was independent of food intake.

3. The food intake correlated with the nutritive value of the protein measured by N.P.U. or P.E.R. For N.P.U. the relation was $y^{2}=67 x-389$ I $(y=$ N.P.U., $x=$ food intake in $\mathrm{g} / 100 \mathrm{~g}$ body weight), and for P.E.R. $y^{2}+20 y=\mathrm{I} \cdot 55^{x}-135^{\circ} 4$.

4. The consumption of diets containing synthetic amino-acids was only half that of protein diets of similar N.P.U. This reduced consumption depressed the P.E.R.'s so that the relation between P.E.R. and N.P.U. found with proteins did not hold for synthetic amino-acid mixtures.

5. The P.E.R.'s of the proteins correlated highly with N.P.U.'s, the relation being very similar to that found by Block \& Mitchell (1946-7), despite the fact that the data of these authors were obtained from many different laboratories.

6. It was shown that N.P.U.'s can be correlated with negative P.E.R.'s (loss of weight in $\mathrm{g} / \mathrm{g}$ protein eaten).

I wish to thank Miss Sheila Haizelden for assistance in carrying out these experiments and for care of the animals.

\section{REFERENCES}

Barnes, R. H., Maack, J. E., Knights, M. J. \& Burr, G. O. (1945). Cereal Chem. $22,273$.

Bender, A. E. (1955). Proc. Nutr. Soc. 14, xiii.

Bender, A. E. \& Miller, D. S. (1953). Biochem. F. 53, vii.

Block, R. J. \& Mitchell, H. H. (1946-7). Nutr. Abstr. Rev. r6, 249.

Fixsen, M. A. B. (1934-5). Nutr. Abstr. Rev. 4, 447.

Folley, S. J., Henry, K. M. \& Kon, S. K. (1947). Brit. F. Nutr. I, 39.

Hamilton, T. S. (1939). F. Nutr. 17, 565. 
Henry, K. M., Kon, S. K. \& Watson, M. B. (1937). Milk and Nutrition, Part 1, p. 37. Reading: National Institute for Research in Dairying.

Kik, M. C. (1938). Bull. Ark. agric. Exp. Sta. no. 352.

Miller, D. S. \& Bender, A. E. (1955). Brit. F. Nutr. 9, $3^{82}$.

Mitchell, H. H. (1924). Physiol. Rev. 4, 424.

Mitchell, H. H. (1944). Industr. Engng Chem. (Anal.), 16, 696.

Mitchell, H. H. \& Carman, G. G. (x926). Amer. F. Physiol. 76, 398.

Rose, W. C., Smith, L. C., Womack, M. \& Shane, M. (1949). F. biol. Chem. r81, 307.

Rutgers University: Bureau of Biological Research (undated). Cooperative Determinations of the Amino Acid Content, and of the Nutritive Value of Six Selected Protein Food Sources. 1946-1950. New Brunswick: Rutgers University.

Stewart, R. A., Hensley, G. W. \& Peters, F. N. Jr. (r943). F. Nutr. 26, 5 I9.

White, P. L., Alvistur, E., Dias, C., Viñas, E., White, H. S. \& Collazos, C. (1955). F. agric. Fd Chem. 3, 531 .

\title{
Microbiological evaluation of protein quality with Tetrahymena pyriformis $\mathrm{W}$
}

\section{Characteristics of growth of the organism and determination of relative nutritive values of intact proteins}

\author{
BY W. R. FERNELL AND G. D. ROSEN \\ Research Department, $\mathcal{F}$. Bibby and Sons Ltd, Liverpool
}

(Received 4 Fanuary 1956)

In assays of protein quality, factors that determine the nutritive value of a protein are not the same for all animal species. The term, nutritive value of a protein, has exact significance only in terms of a selected physiological response in a given species. In some circumstances, however, animal feeding trials are too time-consuming and expensive, and indirect or empirical methods have to be employed.

Of the many factors affecting protein quality, the essential amino-acid composition is considered to be the most fundamental. According to the 'limiting amino-acid concept' the nutritive value of a protein is determined by the availability of the most deficient essential amino-acid as judged by the requirements of the animal. Block \& Mitchell (1946-7) have rated proteins on a 'chemical score' basis whereby the aminoacid composition of a protein is compared with the composition of whole-egg protein, claimed to be completely utilized in the nutrition of the growing rat. The chemical score is the percentage deficit in the limiting essential amino-acid subtracted from 100. Despite a high degree of correlation with 'protein efficiency ratios' and 'biological values' for the growing rat, Block \& Mitchell point out that perfect correlation cannot be expected.

It is known that the order of release of amino-acids and the extent of hydrolysis play an important part in the protein nutrition of an animal and, in relating the results of chemical and microbiological assays of amino-acids to the requirements of a particular species, the assumption is made that the total amino-acid complement is available for 